\title{
Traditional phytotherapy used by the rural peoples of Hamirpur District of HP in the treatment of sexually transmitted diseases mainly Gonorrhea and Syphilis
}

\author{
R Choyal, N Kumar \& AK Dular
}

Journal of Agriculture and Ecology

ISSN: 2456-9410

Volume: 4

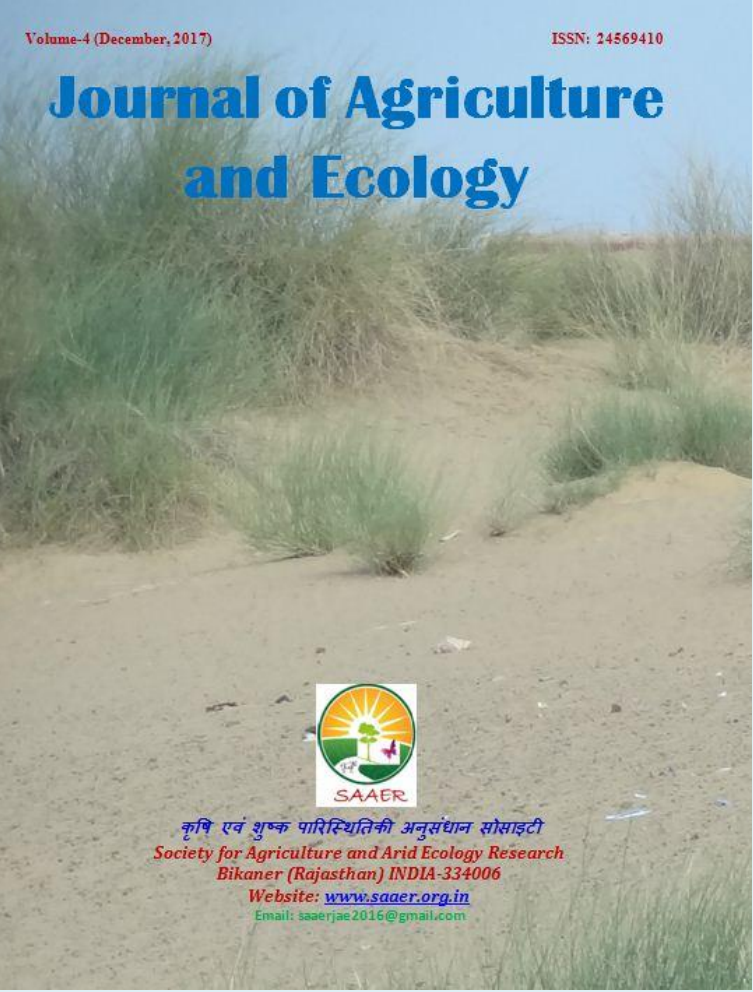

Journal of Agriculture and Ecology (2017) 4: 51-56 http://doi.org/10.53911/JAE.2017.4207 


\title{
Traditional phytotherapy used by the rural peoples of Hamirpur District of $\mathrm{HP}$ in the treatment of sexually transmitted diseases mainly Gonorrhea and Syphilis
}

\author{
$\mathrm{R}$ Choyal $^{1}, \mathrm{~N} \mathrm{Kumar}^{2} \& \mathrm{AK}$ Dular $^{1} \square$ \\ ${ }^{1}$ Department of Environmental Science, M.G.S. University, Bikaner (Rajasthan) \\ ${ }^{2}$ Department of Botany, Gautam Group of College, Hamirpur (H.P) \\ Corresponding author: AK Dular, E-mail: dularakenviromgsu@gmail.com
}

\begin{abstract}
Article Info
Article history

Received: 20 August, 2017

Accepted: 30 October, 2017

Available online: 30

November 2017

Key Words: Ethno-

medicine, primary health

care, Hamirpur
\end{abstract}

Abstract
Indigenous knowledge about particular floral diversity of an area is necessary for the identification of plants and their traditional uses for the purpose such as for food, fibres, fertilizer, fodder, fuel ritual and medicinal importance. In present paper the emphasis will be given on medicinally importance plants for primary health care. The present paper reveals that there are sixteen plants species which belongs to thirteen families are used for therapeutical or traditional uses as indigenous plants of Hamirpur district for the primary health care or treatment of sexually transmitted diseases.

Copyright (C2017 Choyal et al., This is an open access article published under the terms of the Creative Commons Attribution License, which permits unrestricted use, distribution, and reproduction in any medium, provided the original work is properly cited.

Preferred citation: Choyal R, Kumar N \& Dular AK. 2017. Traditional phytotherapy used by the rural peoples of Hamirpur District of HP in the treatment of sexually transmitted diseases mainly Gonorrhea and Syphilis. Journal of Agriculture and Ecology, 4: 51-56; http://doi.org/10.53911/JAE.2017.4207.

\section{Introduction}

Hamirpur district is the smallest district of Himachal Pradesh which falls in Shivalik range. This region act as a good hot spot for the herbal plants due its favorable environment and climatic condition. The people who are living in the remote area of this district yet also believe on the local plants and use their products for the treatment of various disease and in case of primary health care, so the documentation of indigenous knowledge about herbal plants and their uses is necessary in case of primary health care (Kumar \& Choyal 2012). Sex is the major source of reproduction in human life but sexually practices needs cleanness of the both partner and sex organs. Sometimes sex gets infected with various types of pathogen and causing disease known as sexually transmitted disease. STDs are infectious disease that is passed between the human during unprotected vaginal, anal or oral sexual contact, these are acquired commonly as a result of sexual intercourse with infected individual. They usually affect the reproductive system but also affect the other system of body.

Some sexually transmitted disease is Chlamydia which is caused by herpes bacteria, genital herpes caused by herpes simplex virus type 1 or type 2 , gonorrhea which is caused by Neisseria gonorrhea bacteria, syphilis which is caused by Treponema pallidium bacteria, 
hepatitis-B caused by hepatitis-B virus and AIDS (Acquired immune deficiency syndrome) which is caused by HIV virus (Human immunodeficiency virus) etc. Among these problems gonorrhea, syphilis are the common problems of the study area. Gonorrhea is a bacterial disease and the symptoms of the disease are thick yellowish urethral discharge from penis or painful urination, in female spread through uterine tube to lower part of the abdominal cavity resulting in pelvic inflammatory disease and which can cause sterility. Syphilis is a chronic infectious bacterial disease and the symptoms of this disease are sores on usually genital or mouth, rashes after six months later, several years with no symptoms as infection spread finally damage to heart liver nerves and brain nerves. This is focused on common sexually transmitted problem study area for which local people uses the local plants and their parts or products in their treatment. The paper document the use of 16 local plants belonging to 13 different families for the treatment of the sexually transmitted disease of study area (Sharma \& Chouhan 2000).

\section{Materials and methods}

Field surveys were carried out for getting the indigenous knowledge about uses of plants for the treatment of sexually transmitted disease in the different localities of study area during this research. The first hand information was recorded on the plants used as home remedies for the treatment of sexually transmitted disease through personal interviews or local contact with people of different remote localities of study area. The collected plant specimen were preserved in the form of herbarium and identified with the help of Choudhary $\mathrm{HJ}$ and Bhadwa flora of Himachal Pradesh and other relevant literature were consulted one.

\section{Study area}

Hamirpur district is situated between $76^{\circ} 18^{\prime}-76^{\circ} 44^{\prime}$ East longitude and $31^{\circ} 52^{\prime} 30^{\prime \prime}$ North Latitudes. The track is hilly covered by Shivalik range and the elevation varies from 450-1100 meters. This region possesses unique floral diversity and rich herbal or medicinal wealth which needs exploration This paper explore about the 14 plant species of study area which are used in sexually transmitted disease.

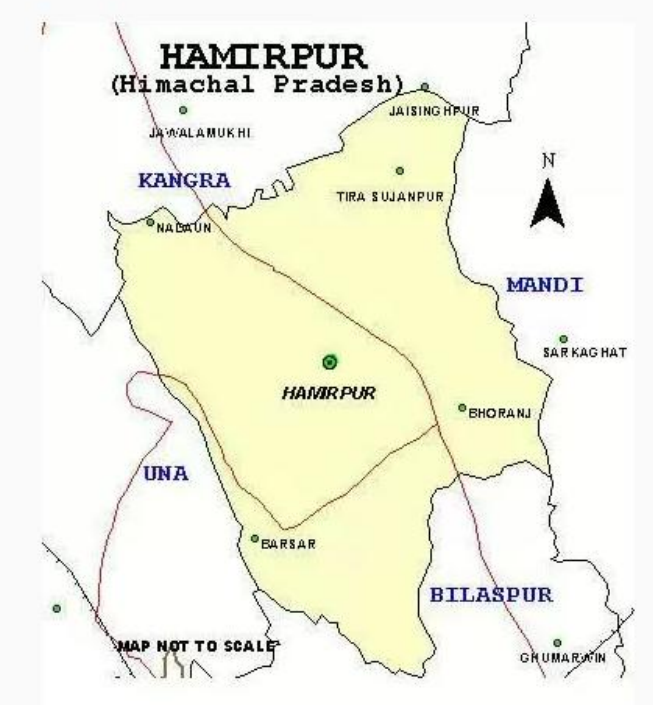

\section{Results and Discussion}

The present study emphasized the use of 16 plant species belonging to 13 families which are used for the treatment of gonorrhea, syphilis and other sexually transmitted diseases. Among these families the Fabaceae 
family is predominant family with three plant species and other families belonging to one or two plant species with their parts used for the treatment of gonorrhea, syphilis and other sexually transmitted diseases. The plant species such as Acacia catechu, Bombax ceiba, Santalum album, Tinospora cordifolia etc are the local plant which is mainly used by local people of Hamirpur district for the treatment of sexually transmitted disease Gonorrhea. Cassia fistula, Curcuma longa, Ficus benghalensis and Solanum nigrumetc are some plants species which are used in the Hamirpur district for the treatment sexually transmitted disease Syphilis (Kala 2005; Prakash \& Aggarwal 2010; Kharwal et al. 2012). (Table $1 \&$ Plate 1 ).

Table 1. A list of medicinal plants species along with their parts in the study region which are used in the treatment of sexually transmitted disease such as -Gonorrhea, syphilis

\begin{tabular}{|c|c|c|c|c|c|}
\hline $\begin{array}{l}\text { S. } \\
\text { No }\end{array}$ & Scientific name & Family & Local name & $\begin{array}{l}\text { Parts } \\
\text { used }\end{array}$ & Folk uses \\
\hline 1. & $\begin{array}{l}\text { Acacia catechu } \\
\text { (L.F.) Wild. }\end{array}$ & Fabaceae & Khair & Flowers & $\begin{array}{l}\text { The extract of flowers } \\
\text { is used in case of } \\
\text { gonorrhea. }\end{array}$ \\
\hline 2. & $\begin{array}{l}\text { Bombax ceiba } \\
\text { Linn. }\end{array}$ & Bombaceae & $\begin{array}{l}\text { Semal, } \\
\text { semul }\end{array}$ & $\begin{array}{l}\text { Seed and } \\
\text { bark }\end{array}$ & $\begin{array}{l}\text { Decoctionof seed and } \\
\text { bark is used for the } \\
\text { treatment of gonorrhea. }\end{array}$ \\
\hline 3 & $\begin{array}{l}\text { Calotropis } \\
\text { gigantean Linn. }\end{array}$ & Asclepidaceae & Safe, aak & $\begin{array}{l}\text { Leaves } \\
\text { and root }\end{array}$ & $\begin{array}{l}\text { The paste of roots and } \\
\text { leaves is useful in case } \\
\text { of syphilis. }\end{array}$ \\
\hline 4 & $\begin{array}{l}\text { Cannabis sativa } \\
\text { Linn. }\end{array}$ & Cannabaceae & Bhang & Leaves & $\begin{array}{l}\text { Paste of leaves is used } \\
\text { in case of gonorrhea. }\end{array}$ \\
\hline 5 & $\begin{array}{l}\text { Cassia fistula } \\
\text { Linn }\end{array}$ & Fabaceae & $\begin{array}{l}\text { Amltas, } \\
\text { aliah }\end{array}$ & Roots & $\begin{array}{l}\text { The root paste is used } \\
\text { in the treatment of } \\
\text { syphilis. }\end{array}$ \\
\hline 6 & $\begin{array}{l}\text { Cinnamomum } \\
\text { tamala } \\
\text { Nees\&Ebesm }\end{array}$ & Lauraceae & Tejpata & Bark & $\begin{array}{l}\text { Bark extract is used in } \\
\text { case of gonorrhea }\end{array}$ \\
\hline 7 & $\begin{array}{l}\text { Curcuma longa } \\
\text { L. }\end{array}$ & Zingiberaceae & Haldi & Rhizome & $\begin{array}{l}\text { Paste powdered } \\
\text { Rhizome is used in } \\
\text { case of syphilis }\end{array}$ \\
\hline 8 & $\begin{array}{l}\text { Cynodon } \\
\text { dactylon (Linn.) } \\
\text { Pers. }\end{array}$ & Poaceae & $\begin{array}{l}\text { Dhrub, } \\
\text { doob grass }\end{array}$ & $\begin{array}{l}\text { Whole } \\
\text { plant } \\
\text { material }\end{array}$ & $\begin{array}{l}\text { The whole plant } \\
\text { material extract is used } \\
\text { in }\end{array}$ \\
\hline 9. & $\begin{array}{l}\text { Erythrina } \\
\text { suberosa Roxb. }\end{array}$ & Fabaceae & Prair & $\begin{array}{l}\text { Bark and } \\
\text { leaves }\end{array}$ & $\begin{array}{l}\text { Powder of bark and } \\
\text { leaves is useful in case } \\
\text { of gonorrheal disease. }\end{array}$ \\
\hline 10. & $\begin{array}{l}\text { Ficus } \\
\text { benghalensis } \\
\text { Linn. }\end{array}$ & Moraceae & Bad & Root & $\begin{array}{l}\text { Root paste is useful in } \\
\text { the treatment of } \\
\text { syphilis. }\end{array}$ \\
\hline
\end{tabular}


11. Ficus religiosa Moraceae Root Root powder is useful Linn.

12. Moringa Moringaceae Sunjahana Seed oleifera Lam. in care of gonorrhea.

13. Ocimum Lamiaceae Bhabri Whole Decoction of whole basilicum Linn. plant plant material is useful material in case of gonorrhea.

14. Santalum album Santalaceae Linn.

Safedchand Wood an

15. Solanum nigrum

Solanaceae

Makoi

Leaves

Seeds are roasted and powdered which are mixed with coconut oil is applied in case of Sexually transmitted disease. Linn.

\section{Tinospora} cordifolia (Wild.) Miers.

Menispermaceae

\section{Giloe, Guljaya}

Whole plant material

Sanden wood oil is useful for the treatment of gonorrhea.

The paste of leaves and powder of leaves are used in the treatment of syphilis.

Whole plant martial decoction is used for the treatment of gonorrhea.

Plate 1. A list of medicinal plants species with photographs which are used in the treatment of sexually transmitted disease such as Gonorrhea, syphilis

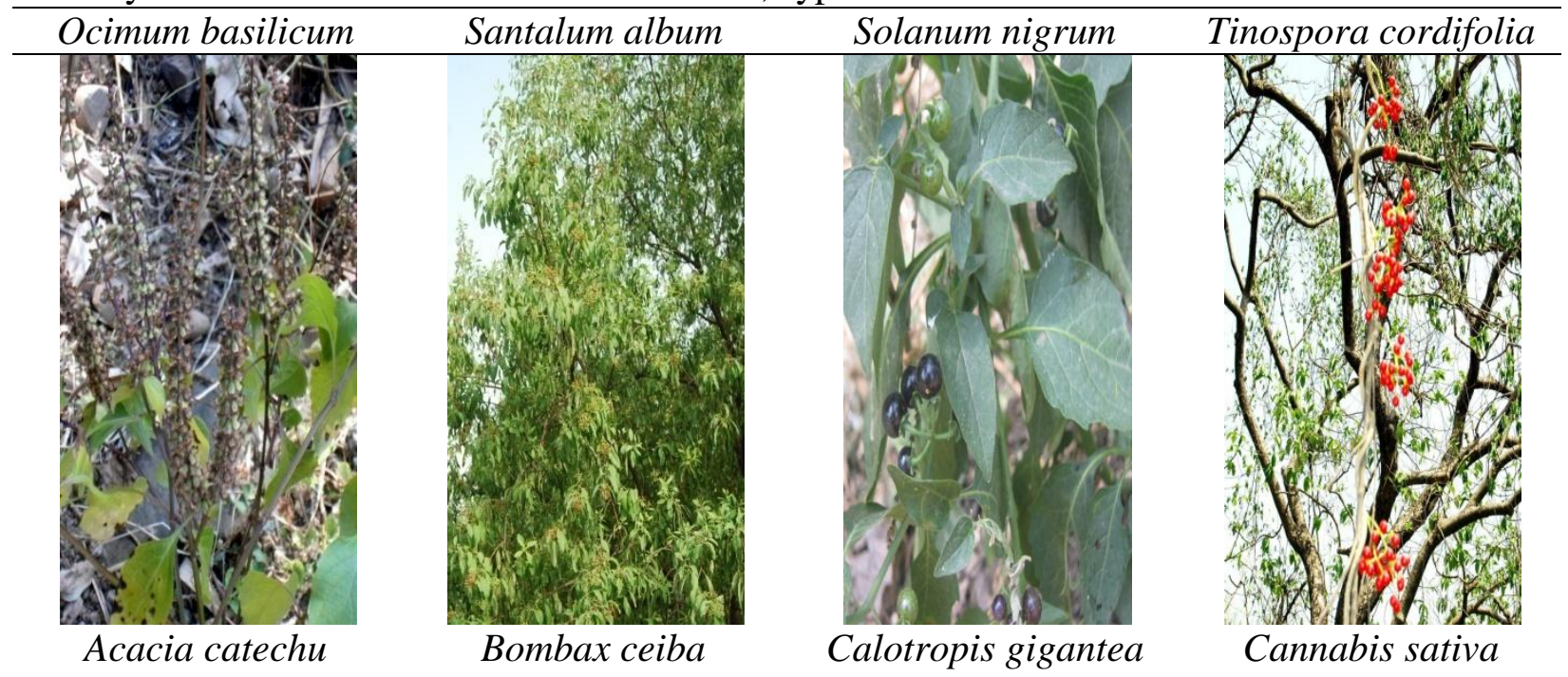



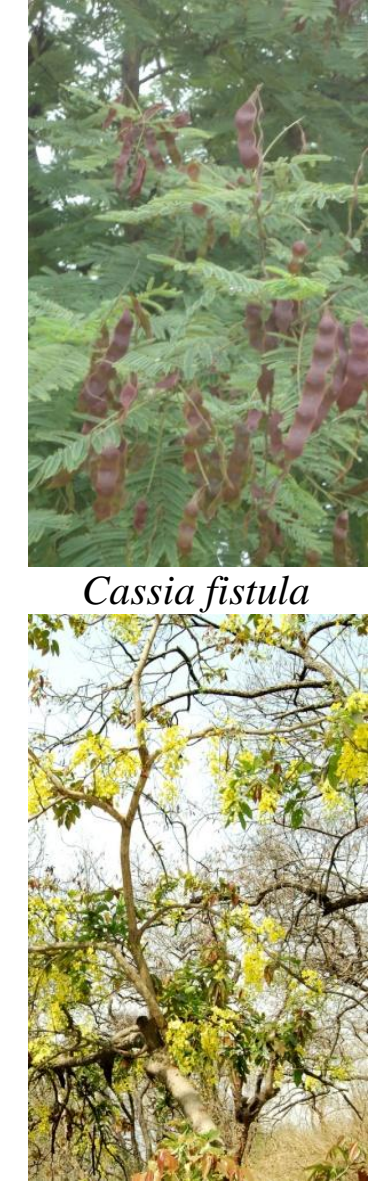

Erythrina suberosa

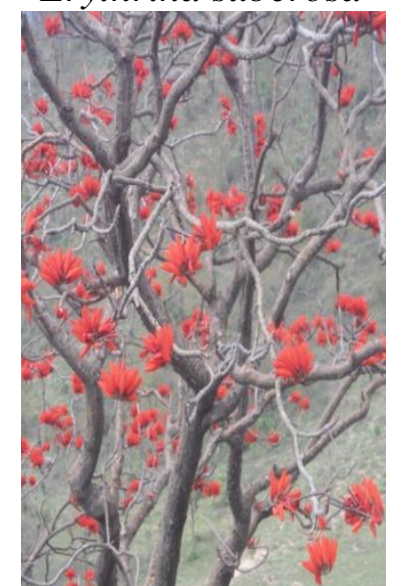

\section{Conclusion}

Indigenous knowledge about the local floral diversity and about the use of local plants for primary health care should be recorded and preserved. So, that next
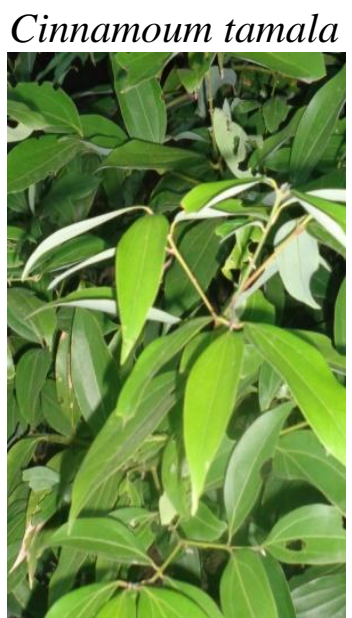

Ficus benghalensis

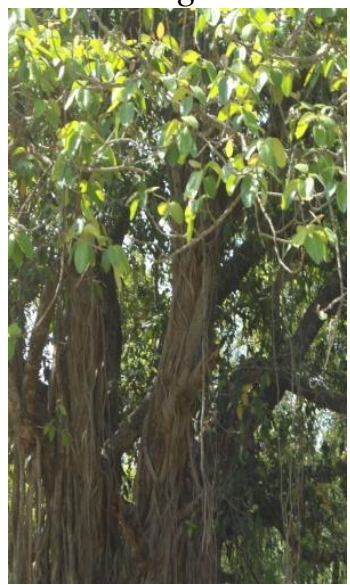

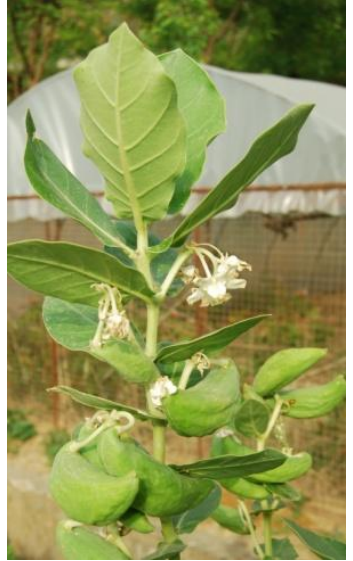

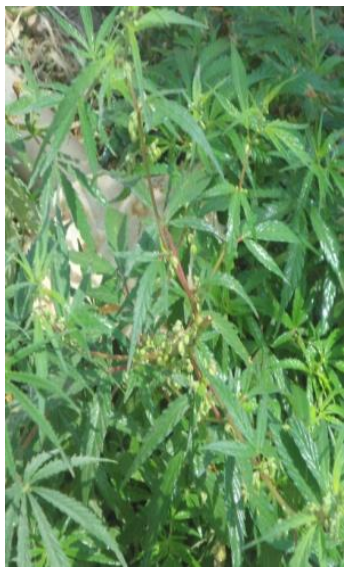

Curcuma longa

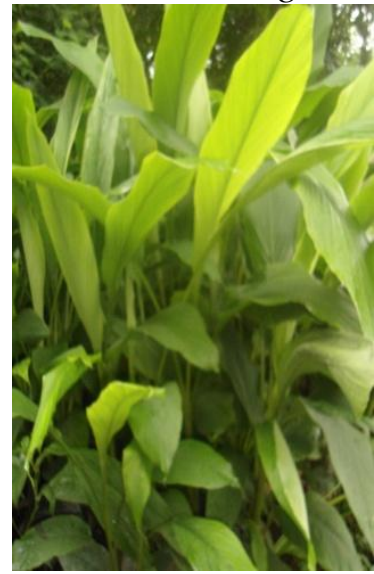

Ficus religiosa

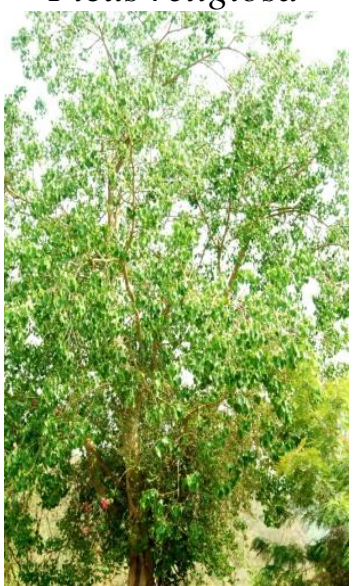

Moringa oleifera

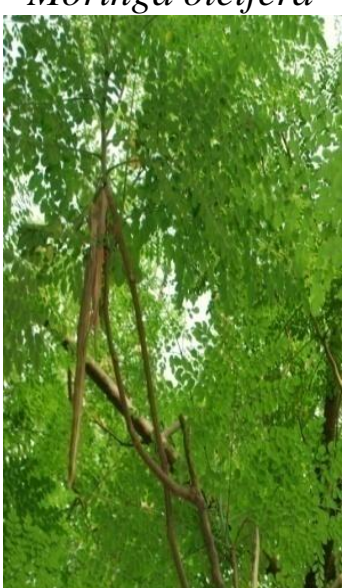

generation should get and their benefit of the knowledge local floral diversity and their plant based traditional phyto-therapy for the treatment of various health problems. This step will prove necessary step in the conservation of traditional knowledge and 
about the protection of local plants of medicinal importance of study area.

\section{Acknowledgement}

Authors are thankful to the indigenous people of study area for their valuable guidance and help during research work.

\section{References}

Kala CP. 2005. Ethnomedicional botany of the Aptani in the Eastern Himalaya region of India. Journal of Ethnobiology and Ethnomedicine, 10(11): 33-39.

Kharwal, Anjna D \& Rawat DS. 2012. Ethnobotanical notes on indigenous herbal shampoos of Shivalik hills, Himachal Pradesh,(India). Plant Science Feed, 2(6): 88-90.
Kumar, N \& Choyal R. 2012. Hamirpur district of Himachal Pradesh for the treatment of Arthritis rheumatism and other inflammatory disorder. Indian Journal of Plant Science, 2012 Vol. 1 (2-3): 1-5.

Prakash V \& Aggrawal A. 2010. Traditional uses of ethnomedicinal plants of lower foot-hills, Himachal Pradesh.

Sharma PK \& Chauhan NS. 2000. Ethnobotanical studies of Gaddi-a tribal community of Kangra district, Himachal Pradesh, in :Kohli, R.K., Singh H.P, Vij S.P, Dhar K.K., Batish D.R. and DhimanB.K. (eds) Man and Forest, Punjab University Chandigarh, 301-302. 